\title{
The making of an agricultural classic: farmers of forty centuries or permanent agriculture in China, Korea and Japan, 1911-2011
}

\author{
John Paull \\ Institute of Social and Cultural Anthropology, University of Oxford, Oxford, UK; Corresponding Author: john.paull@anthro.ox.ac.uk
}

Received 17 May 2011; revised 23 June 2011; accepted 19 July 2011.

\section{ABSTRACT}

Few agriculture books achieve the status of 'classic'. F. H. King's book Farmers of Forty Centuries or Permanent Agriculture in China, Korea and Japan was privately published in Wisconsin, USA, in 1911. The book had an inauspicious start, and the longevity and acclaim that this book has since achieved must have been, then, barely conceivable. The author was dead, the book was incomplete, and there was no commercial publisher. Yet through a combination of perhaps luck and circumstance the book was 'resurrected' in 1927 by a London publisher, Jonathan Cape, who then kept it in print for more than two decades. The London issue of King's book was favorably cited in the 1930s and 1940s by leading agriculture and organic agriculture writers including: Lord Northbourne, Eve Balfour, Viscount Lymington, Albert and Louise Howard in Britain; Ehrenfried Pfeiffer in Switzerland; Jerome Rodale in the USA; and Stanton Hicks in Australia. These endorsements served to entrench King's book as a 'classic'. Jerome Rodale reintroduced the book to a US audience with an edition published by his Organic Gardening Press, c.1949. King's book arose out of his discontent with the views promulgated by the US Department of Agriculture (USDA), he differentiated the Asian agriculture he encountered as 'permanent agriculture', he provided a detailed account of the ancien régime organic agriculture of China, Korea and Japan, he called for a "world movement" for agricultural reform, and his book was been taken as a validation of the principles of organic agriculture. At least twenty six impressions of Farmers of Forty Centuries have been published in the past century; ten of these appeared dur- ing the first nine decades, while 16 have appeared in the past decade.

Keywords: Organic Agriculture; Organic Farming; Biodynamic Agriculture; Franklin Hiram King; Cyril Hopkins; Jonathan Cape; London.

\section{INTRODUCTION}

In his 1940 manifesto of organic farming, Look to the Land, Lord Northbourne described Farmers of Forty Centuries as a "classic" [1] and as "that great book by Professor King et al. Farmers of Forty Centuries, a book which no student of farming or social science can afford to ignore” [1]. Eve Balfour in her 1943 book The Living Soil followed Northbourne's lead and also described Kings book as a "classic" [2]; she wrote that: "By adhering to this principle [of composting] the Chinese peasant has intensively and continuously cropped his soil without loss of fertility for forty centuries” [2].

Despite the enthusiasm and endorsement of Northbourne, Balfour and others, the book Farmers of Forty Centuries or Permanent Agriculture in China, Korea and Japan did not appear destined for greatness when it first appeared in 1911 [3]. An agriculture book that is a classic is something rare, and for this book, written by F. H. King, the beginning must have seemed, at the time, even more inauspicious than most. There was no commercial publisher, the author was dead, and the manuscript was incomplete. In his lifetime, King was neither a celebrated writer nor a prominent public figure. A few years prior he had made an acrimonious departure from the US Department of Agriculture. Added to these unlikely recommendations, Farmers of Forty Centuries was a book about the ancient practices of the Orient and it was offered into the US market which was focussed on, and seemingly mesmerised by, Occidental techno-fixes.

The concept of 'permanent agriculture' was, at least partly, the outcome of an internecine war, between the 
Bureau of Soils of the United States Department of Agriculture (USDA) and two US professors of agriculture. Cyril George Hopkins (1866-1919) was Professor of Agronomy at the University of Illinois, and Franklin Hiram King (1848-1911) was Professor of Agricultural Physics at the University of Wisconsin. King took up the position of Chief of the Division of Soil Management in the Bureau of Soils of the USDA. For King it was an unhappy appointment, his tenure was brief (1902-1904), and his departure was acrimonious [4].

King's research findings clashed with the prevailing USDA orthodoxy being promulgated by Milton Whitney, the chief of the USDA Bureau of Soils. Whitney ultimately forced King's resignation [4]. Whitney vetoed the publication of three of King's research papers during King's brief stint at the USDA [4-6]. In 1904, a contemporary of King and Hopkins, E. W. Hilgard, accused the USDA's censorship of soil science as a "return to medievalism" and accused it of "a deliberate attempt to suppress the truth" [5]. Hilgard called on scientists to "protest against the dictation of official orthodox science of any kind, from headquarters at Washington" [5].

King objected to Whitney and Cameron's theory, published in 1903, that the nutrients in soil will last indefinitely without replenishment [7], and to Whitney's 1906 proposition that manures work by offsetting the "toxic excreta" of plant roots [8]. Whitney boasted that USDA Soil Bulletins were used as text books in US agricultural colleges [9]. The times were described as "tumultuous" [6] and as occasioning "some extraordinary invective" [6]; and certainly there was robust disagreement between the professors and the USDA.

Hopkins and King were on a collision course with the USDA. Hopkins was an articulate critic and he was scathing of the USDA: "the erroneous teaching so widely promulgated by the federal Bureau of Soils is undoubtedly a most potent influence against the adoption of positive soil improvement in the United States, because it is disseminated from the position of highest authority. Other peoples have ruined other lands, but in no other country has the powerful factor of government influence ever been used to encourage the farmers to ruin their lands" [10].

Hopkins, in 1910, denounced the USDA: "Whitney and Cameron have revived Decandolle's theory of toxic excreta from plant roots, in support of another more radical theory announced by them, to the effect that soils do not wear out or become depleted by cultivation or cropping. While this theory is advanced with no adequate foundation and in direct opposition to practical experience and to so many known facts of mathematics, chemistry, and geology, that it is in itself quite unworthy of further consideration, the fact is that it has been promulgated by Professor Whitney as Chief of the United States Bureau of Soils, and by Doctor Cameron, as the chief chemist of the same Bureau; and, consequently, it cannot be ignored" [9].

Hopkins endorsed King at the expense of the USDA: "It appears, however, that the conclusions of Whitney and Cameron even concerning the nonrelationship between crop yields and water-soluble plant food are wrong”. Professor F. H. King, a most careful investigator of the highest integrity, as the result of two years' experiments, including many determinations made during the crop season, before severing his connection with the Bureau of Soils, was led to $\cdots$ [contrary] conclusions" [9].

The enduring outcomes of this academic feud with the USDA included King's visit to the Orient, in 1909, and four books on 'permanent agriculture' from 1910 to 1913 (Table 1). The first of those books was Hopkins' Soil Fertility and Permanent Agriculture [9] (Plate 1) in which he vented his frustration with the USDA orthodoxy of the day, and praised King.

Although King's book was not published until 1911, Hopkins' 1910 book commented (correctly) that King had "recently visited the Orient" and he reported some of King's results in his own book [9]. The three works by Hopkins were clearly targeted at different audiences and they were written in quite different styles. After Soil Fertility and Permanent Agriculture (649 pages, 1910), came The Story of the Soil (362 pages, 1911), and The Farm That Won't Wear Out (80 pages, 1913). All three books championed the concept of permanent agriculture. In The Farm That Won't Wear Out, Hopkins concluded that: "the intelligent improvement of his soil, in systems of permanent agriculture, is the most profitable business in which the farmer and land owner can engage" [11]. Each of Hopkins' three books found publishers in their day, but not since, and his three works are now all but forgotten a common fate of agriculture books written a century ago.

Table 1. Bibliography of 'Permanent Agriculture'.

\begin{tabular}{ccc}
\hline Date & Author & \\
\hline 1910 & $\begin{array}{l}\text { Cyril G. } \\
\text { Hopkins }\end{array}$ & Soil Fertility and Permanent Agriculture \\
1911 & $\begin{array}{l}\text { Franklin } \\
\text { H. King }\end{array}$ & $\begin{array}{r}\text { Farmers of Forty Centuries or Permanent } \\
\text { Agriculture in China, Korea and Japan }\end{array}$ \\
& $\begin{array}{l}\text { Cyril G. } \\
\text { Hopkins }\end{array}$ & $\begin{array}{r}\text { The Story of the Soil: From the Basis of } \\
\text { Absolute Science and Real Science }\end{array}$ \\
& $\begin{array}{l}\text { Cyril G. } \\
1913\end{array}$ & The Farm That Won't Wear Out \\
\hline
\end{tabular}




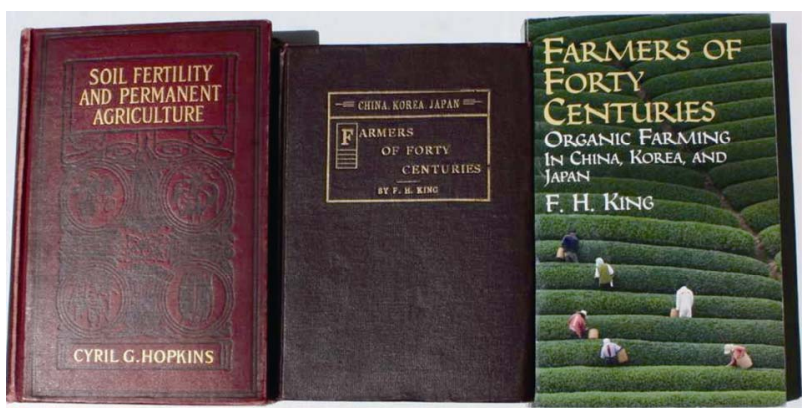

Plate 1. US Professors of Agriculture, Hopkins and King, disputed the USDA view of fertility and wrote of 'Permanent Agriculture’: Hopkins in 1910 (left); and King in 1911 (centre). King is still in print; the 2004 reprint by Dover changed 'Permanent Agriculture' to 'Organic Farming' (right) (Photo: J. Paull).

Having quit the USDA, King embarked on an eight month oriental agricultural tour. He arrived in Yokohama in February 1909 and toured extensively in China, Japan, and, to a much lesser extent, Korea [3,12]. King died with the book incomplete-it lacks the final chapter and hence his conclusions.

In the Introduction to his book, King explains his project: "We had long desired to stand face to face with Chinese and Japanese farmers; to walk through their fields and to learn by seeing some of their methods, appliances and practices which centuries of stress and experience have led these oldest farmers in the world to adopt. We desired to learn how it is possible, after twenty and perhaps thirty or even forty centuries, for their soils to be made to produce sufficiently for the maintenance of such dense populations ... we were instructed, surprised and amazed at the conditions and practices which confronted us whichever way we turned; instructed in the ways and extent to which these nations for centuries have been conserving and utilizing their natural resources” [3].

King foresaw a world movement for agricultural reform: "China, Korea and Japan long ago struck the keynote of permanent agriculture, but the time has now come when they can and will make great improvements, and it remains for us and other nations to profit by their experience, to adopt and adapt what is good in their practice and help in a world movement for the introduction of new and improved methods" [3].

Farmers of Forty Centuries was described as a book of “450 pages, 246 illustrations; Price \$2.50" [3]. It is a book of 18 chapters, of which the final one, 'Message of China and Japan to the World', is absent, due to the author's death.

\section{PUBLISHING, THE FIRST CENTURY}

In contrast to Hopkins' books, which attracted com- mercial publishers, King's Farmers of Forty Centuries were initially privately published by his widow, and the publisher appears as "Mrs. F. H. King". The London publisher, Jonathan Cape, rescued King's book from looming oblivion and successfully republished Farmers of Forty Centuries in London in 1927 [13].

Between the time when King's book first appeared in 1911 in the USA, and its reappearance in Britain in 1927, there had been some profound changes in the practice of agriculture. Fritz Haber and Carl Bosch in Germany had successfully demonstrated their method of 'fixing' nitrogen from the air, in 1909, and this was rapidly and successfully commercialised on an industrial scale. The 'Haber-Bosch Process' ushered in an era of cheap synthetic nitrogenous fertilisers for farmers [14]. By the time Jonathan Cape took up Farmers of Forty Centuries there was a developing questioning and discontent at this input-intensification of farming. Rudolf Steiner's Agriculture Course held in 1924 at Koberwitz (now Kobierzyce, Poland) was an early response to the wave of change sweeping agriculture [15]. The impulse of Steiner's course gained momentum and Ehrenfried Pfeiffer published Bio-Dynamic Farming and Gardening in 1938, with editions appearing in five languages [16].

The Jonathan Cape issue of Farmers of Forty Centuries appeared in Britain at a time when agriculture was under scrutiny and discussion, and further Jonathan Cape impressions followed in 1933, 1939, and 1949. In the USA, almost four decades elapsed from the first publication Farmers of Forty Centuries until Jerome Rodale reissued the book under his imprint 'Organic Gardening Press', Emmaus, PA, circa1949. By this time, Pfeiffer had moved from Switzerland to the US, and he was actively promoting biodynamic agriculture, Northbourne had introduced the term 'organic farming' [17], and Rodale had launched the periodical Organic Farming and Gardening [18]. The foundational books of the biodynamic and organic movements, Pfeiffer's Bio-Dynamic Farming and Gardening, and Northbourne's Look to the Land, both referred to the Jonathan Cape imprint of King's Farmers of Forty Centuries.

The Waste Products of Agriculture, published in 1931 by Howard and Wad, owes a debt to King's Farmers of Forty Centuries. The Howard \& Wad title echoes the title of King's Chapter IX: "The Utilization of Waste" [3]. The opening sentence of Howard \& Wad is an echo of King: "The maintenance of fertility of the soil is the first condition of any permanent system of agriculture" [19]. King's photograph of a compost pit [3] and Howard and Wad's photographs [19] are strikingly similar. Howard \& Wad also cited "Wagner, W. Die Chinesische Landwirtschaft [trans: Chinese Agricultural], Berlin, 1926” [19]. Of the so called 'Indore method' of com- 
posting, Howard's wife, Louise Howard, stated that: “it seemed obvious to try out the methods which had been known in China for over four thousand years" [20], and she declared that: "We cannot do better than what the Chinese do" [20]. Northbourne referred to methods of practicing organic farming, describing one category: "The second category I call the Indore-Hunza-Chinese method - Chinese for short” [21].

Viscount Lymington cited King's book in his 1938 book Famine in England [22], as did the authors of the developing biodynamics and organics literature. Advocates citing Farmers of Forty Centuries included: Ehrenfried Pfeiffer in 1938 in Switzerland [23]; Eve Balfour in 1943 in England [2]; Stanton Hicks in 1945 in Australia [24]; and Jerome Rodale in 1945 in USA [25]. The edition of Farmers of Forty Centuries to which Pfeiffer, Northbourne, Balfour, Hicks, Rodale, and the Howards referred, was the UK reprint by Jonathan Cape [13] (none cited the first edition).

At least 26 impressions or editions of Farmers of Forty Centuries have appeared in English under a variety of imprints over the century since the first edition of 1911 (Figure 1). There have been three decades in which no new editions appeared (Figure 1). The decade of most publishing activity is the last decade (2001-2010) (Figure 1); and the year of greatest activity has been 2010 with five new issues (Figure 2). In the 1920s and the 1930s Jonathan Cape had the field to themselves, and this persisted until King was finally republished in the USA by Organic Gardening Press (now Rodale Press) in about 1949. Rodale Press has since then issued impressions in 1972, 1973, 1978, and 1990.

In March 2004, Steve Solomon and Charles Aldorondo uploaded a digital file of Farmers of Forty Centuries to Project Gutenberg (www.gutenberg.org)

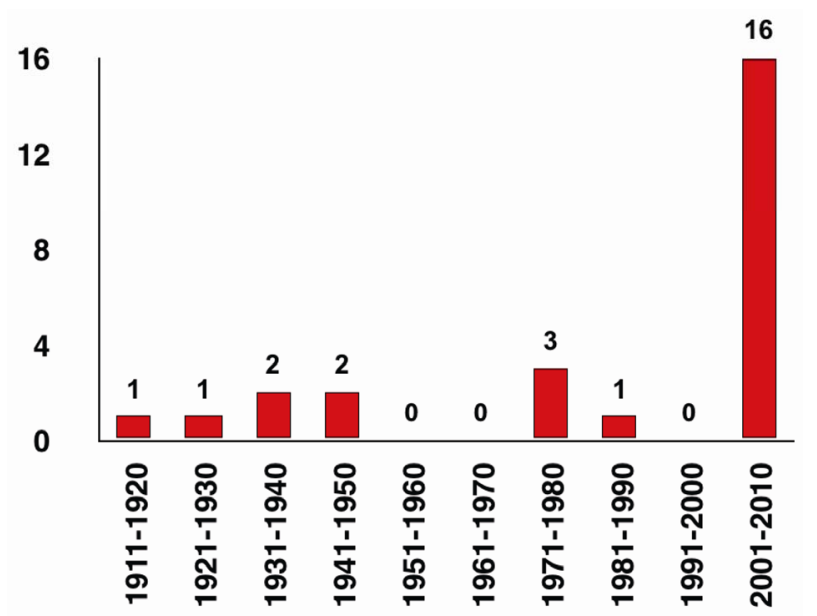

Figure 1. A century of published editions or impressions of Farmers of Forty Centuries, 1911-2010.

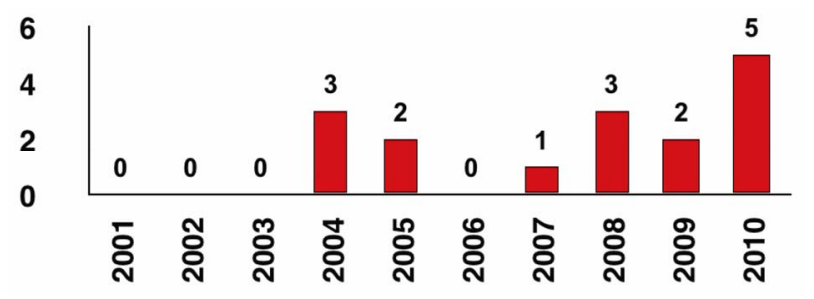

Figure 2. A decade of published editions or impressions of Farmers of Forty Centuries, 2001-2010.

as EBook \#5350. This made King's text freely available and searchable to all those with internet access, and it remains thus today. From 1990 to 2004 there had been no new hardcopy editions; then, coinciding with the release of the digital Farmers of Forty Centuries, Dover also published in March 2004, their ill-considered retitled edition as: Farmers of Forty Centuries: Organic Farming in China, Korea and Japan. This redacted title has nothing to recommend it-other than as a dubious marketing ploy. It is anachronistic to redact 'permanent' to 'organic' since the term 'organic agriculture' had no currency until Northbourne introduced the term 'organic farming' in 1940, and it is neither a term that King used nor would have recognised. Dover did not redact any of the body of King's text, so 'organic' stands alone on the cover of their book as a misleading anachronism.

After the Gutenberg and Dover Farmers of Forty Centuries appeared in 2004, there has been a veritable 'explosion' of impressions with more new impressions and editions of King being published in the past decade than in the previous nine decades. Since the Dover edition, there have been editions by: Kessinger Publishing (2004); Indy Publish (2005); The Press at Toad Hall (2005); Biblio Bazaar (2007); Bastian Books (2008); Biblio Life (2008); Global Oriental (2008); Icon Group International (2009); Pranava Books (2009); Textstream (2010); General Books LLC (2010); ValdeBooks (2010); HardPress Publishing (2010); and Nabu Press (2010).

\section{DISCUSION AND CONCLUSIONS}

The publishing history of Farmers of Forty Centuries has been uneven, but it is now enjoying a 'golden era'. In the decade just passed, sixteen separate publishers offered editions of King's book. This new proliferation has coincided with technological advances and opportunities including the development of print on demand (POD) technologies for book production, faster scanners, opportunities for short run publishing, online international bookshops, for example Amazon.com, and developing opportunities for order taking and fulfilment, all facilitated by the lapse of copyright and by the growing interest in organic agriculture.

With the proliferation of Farmers of Forty Centuries 
in digital and print formats, its future now seems secure. The 'rescue' of the book by the London publisher Jonathan Cape in 1927 was a resurrection for the book which was, by then, all but forgotten. The consensus of endorsement of the book by the early organic agriculture pioneers was itself an endorsement of the decision by Jonathan Cape to republish, and it was the London editions that they referenced, rather than the original.

Although the book Farmers of Forty Centuries continues to gain currency, its defining meme, 'permanent agriculture', has gained little traction. The 1929 book Tree Crops: A Permanent Agriculture [26] is a rare example which has, since King and Hopkins, used the term as a defining element of its narrative. 'Permanent agriculture' was appropriated and contracted to generate the neologism 'permaculture' which appeared in the 1978 Tasmanian book of Mollison \& Holmgren: Permaculture 1: A perennial agriculture system for human settlements [27]. The contraction is confirmed in the title of the second volume: Permaculture Two: Practical design for town and country in permanent agriculture [28].

The book Farmers of Forty Centuries remains of interest for at least four reasons. Firstly was the timing. King's championing of soil husbandry was contemporaneous with the development of synthetic fertilizer technology by Haber and Bosch [29]. King's book preceded the chemical industry's development of synthetic pesticides, and the US seizure of German chemical patents [30]. It was remarkably prescient coming at a time prior to the, then, forthcoming immanent and major upheavals in farming practice, including the transformation of agriculture by the chemical industry.

Secondly, King's book recorded, with an eye for detail, and with precision augmented by statistics, the principles and practice of what we can now describe as ancien régime organic agriculture. His book described agricultural practices across three populous countries which were self sufficient in food and had been feeding large populations, from the same soil, for millennia. Organics advocates have viewed it as an validation of their methods and it remains of interest to organics scholars because of its influence, its persistence, and its testimony.

Thirdly, King, as well as Hopkins, chose a term, in their case 'permanent', that qualified 'agriculture', and thereby differentiated the practice of 'permanent agriculture' from 'orthodox agriculture' as preached by the USDA. The term arose from a conflict, a clash of ideologies, and signalled a cleavage of the territory of agricultural theory and practice into different camps; it a cleavage which remains to this day. As a distinguishing term, 'permanent', was the first of many such distinguishing terms for alternative agricultures. 'Permanent agriculture' emerged in response to, and out of a conflict with, the USDA's view of agriculture. There is the parallel with 'organic agriculture' which emerged, framed as a contest, three decades later as Northbourne's “organic versus chemical farming” [1]. 'Permanent' was a precursor to 'organic', the term which has, in the interim, become the dominant descriptor (and meme) to describe non-orthodox, alternative agriculture.

Fourthly, King called for a "world movement” [3] to introduce and develop permanent agriculture practices. He noted that "China, Korea and Japan long ago struck the keynote of permanent agriculture $\cdots$ it remains for us and other nations to profit by their experience". The call for a "world movement" o alternative agriculture eventually manifested in France, in 1972 as the International Federation of Organic Agriculture Movements (IFOAM) [31].

As China is now adopting organic agriculture on a grand scale [32] there are increasing opportunities to compare, across the divide of a century, places and practices that were documented by King. He described, for example, Chongming Island (King spells it 'Chungming') which is now increasingly adopting modern organic agriculture practices [33].

King's book has a special place in the canon of agricultural writers in general and organic farming in particular, and Farmers of Forty Centuries has earned its standing as a 'classic'. In describing, with the eye of a scientist, an agricultural world that has all but disappeared, the work offers an accessible record of agricultural practices of increasing interest as the world faces the challenges of novel and contested agricultural technologies.

\section{REFERENCES}

[1] Northbourne, L. (1940) Look to the land. Dent, London.

[2] Balfour, E.B. (1943) The living soil: Evidence of the importance to human health of soil vitality, with special reference to post-war planning. Faber and Faber, London.

[3] King, F.H. (1911) Farmers of forty centuries, or permanent agriculture in China, Korea and Japan. Mrs. F. H. King, Madison.

[4] Tanner, C.B. and Simonson, R.W. (1993) Franklin hiram king-pioneer scientist. Soil Science Society of America Journal (SSSAJ), 57, 286-292. doi:10.2136/sssaj1993.03615995005700010049x

[5] Hilgard, E.W. (1904) Soil management. Science, 20, 605608.

[6] Willis, R.J. (2007) The history of all elopathy. Springer, Dordrecht.

[7] Whitney, M. and Cameron, F.K. (1903) The chemistry of soils as related to soil production. USDA Soil Bulletin, \#22.

[8] Whitney, M. (1906) Soil fertility. USDA Farmers’ Bulletin, \#257. 
[9] Hopkins, C.G. (1910) Soil fertility and permanent agriculture. Ginn and Company, Boston.

[10] Hopkins, C.G. (1911) The story of the soil: From the basis of absolute science and real science. The Gorham Press, Boston.

[11] Hopkins, C.G. (1913) The farm that won't wear out. Cyril G. Hopkins, Champaign.

[12] Allen, S.L. (2000) Franklin hiram king (1848-1911) His documents related to East Asia. Madison: University of Wisconsin, Wisconsin.

[13] King, F.H. (1911) Farmers of forty centuries or permanent agriculture in China, Korea and Japan (First UK published edition, 1927). Jonathan Cape, London.

[14] Smil, V. (2001) Enriching the earth: Fritz haber, carl bosch, and the transformation of world food production. The MIT Press, Cambridge.

[15] Paull, J. (2011a) Attending the first organic agriculture course: Rudolf Steiner's agriculture course at Koberwitz, 1924. European Journal of Social Sciences, 21, 64-70.

[16] Paull, J. (2011b) Biodynamic agriculture: The journey from Koberwitz to the world, 1924-1938. Journal of Organic Systems, 6, 27-41.

[17] Paull, J. (2006) The farm as organism: The foundational idea of organic agriculture. Journal of Bio-dynamics Tasmania, 80, 14-18.

[18] Rodale, J.I. (1942). Organic farming and gardening. Rodale Press, Emmaus.

[19] Howard, A. and Wad, Y.D. (1931) The waste products of agriculture: Their utilization as humus. Humphrey Milford, Oxford University Press, London.

[20] Howard, L.E. (1947) The earth's green carpet. Faber and Faber, London.

[21] Northbourne, L. (1942) Farm management (fertility and health). A Kinship in Husbandry Meeting, 18/1/1942,
Merton College, Oxford, 4-7.

[22] Lymington, V. (1938) Famine in England. H. F. \& G. Witherby, London.

[23] Pfeiffer, E. (1938) Bio-Dynamic Farming and Gardening: Soil Fertility Renewal and Preservation. Anthroposophic Press, New York.

[24] Hicks, C.S. (1945) Soil, food and life (the annie B). Cunning Lectures on Nutrition, No. 3, University of Melbourne, Melbourne.

[25] Rodale, J.I. (1945) Pay dirt: Farming and gardening with composts. Devin-Adair Company, New York.

[26] Smith, J.R. (1929) Tree crops: A permanent agriculture. Harcourt Brace, New York.

[27] Mollison, B.C. and Holmgren, D. (1978) Permaculture 1: A perennial agriculture system for human settlements. Hobart: University of Tasmania.

[28] Mollison, B. (1979). Permaculture two: Practical design for town and country in permanent agriculture Stanley. Tagari Publications, Tasmania.

[29] Haber, F. (1920) The synthesis of ammonia from its elements. Nobel Lectures, Chemistry 1901-1921, Elsevier Publishing, Amsterdam.

[30] Hale, W.J. (1934) The farm chemurgic: Farmward the star of destiny lights our way. The Stratford Company, Boston.

[31] Paull, J. (2010) From France to the world: The International Federation of Organic Agriculture Movements (IFOAM). Journal of Social Research \& Policy, 1, 93102.

[32] Paull, J. (2007) China's organic revolution. Journal of Organic Systems, 2, 1-11.

[33] China Economic Review (2011) Organic farming goes high-tech. China Economic Review, 16. 